\title{
Indigenous knowledges as vital contributions to sustainability
}

\section{Miye Nadya Tom ${ }^{1}$ - Elizabeth Sumida Huaman ${ }^{2} \cdot$ Teresa L. McCarty $^{3}$}

Published online: 20 February 2019

(c) UNESCO Institute for Lifelong Learning and Springer Nature B.V. 2019

In this special issue we rethink dominant discourses of development, globalisation and sustainability, focusing on local Indigenous ideas, practices and visions of education that hold direct benefit for Indigenous peoples and broader impacts for all peoples. These contributions exemplify global diversity and respond to a critical question posed at the height of globalisation discourses and still relevant today: "Education for what will prevail in the globalization age?" (Stromquist and Monkman 2000, p. 21). ${ }^{1}$ In an era marked by widening economic and education disparities, and increasing environmental, social and political precarity (Grande 2018), ${ }^{2}$ Indigenous and other non-dominant peoples are rendered most vulnerable. Within the scope of the regions and peoples represented in this issue, we aim to counter that precarity through a critical global dialogue on the significance of Indigenous knowledge systems to education for a sustainable future.

\footnotetext{
${ }^{1}$ Stromquist, N.P. \& Monkman, K. (2000). Defining globalization and assessing its implications on knowledge and education. In N.P. Stromquist \& K. Monkman (Eds), Globalization and education: Integration and contestation across cultures (pp. 3-25). New York: Rowman and Littlefield.

${ }^{2}$ Grande, S. (2018). Aging, precarity, and the struggle for Indigenous elsewheres. International Journal of Qualitative Studies in Education, 31(3), 168-176.
}

Miye Nadya Tom

miyetom@gmail.com

Elizabeth Sumida Huaman

eshuaman@umn.edu

Teresa L. McCarty

teresa.mccarty@ucla.edu

1 San Francisco, CA, USA

2 Comparative International and Development Education in the Department of Organizational Leadership, Policy, and Development, University of Minnesota, Twin Cities, Minneapolis, MN, USA

3 Graduate School of Education and Information Studies and American Indian Studies Program, University of California, Los Angeles, CA, USA 
More than 370 million Indigenous people reside in 90 countries and every continent on earth (UNPFII 2006). ${ }^{3}$ Indigenous peoples speak two-thirds of humankind's 7,000 known spoken languages (McCarty and Coronel-Molina 2017). ${ }^{4}$ Although no universally accepted "official" definition of Indigenous peoples exists, the United Nations Permanent Forum on Indigenous Issues (UNPFII) considers the term to refer to people who self-identify as Indigenous and are accepted as a member of one or more Indigenous communities; have historical continuity with pre-settler societies, territories, languages, cultural practices and political systems; and "resolve to maintain and reproduce their ancestral environments and systems as distinctive peoples and communities" (UNPFII 2006, para. 3). In this definition, sustainability characterises Indigeneity. More specifically, the United Nations identifies Indigenous peoples as "inheritors and practitioners of unique cultures and ways of relating to people and the environment" (UN n.d.). ${ }^{5}$ Perhaps most salient, though, are the self-definitions of Indigenous peoples themselves. As Taiaiake Alfred and Jeff Corntassel assert,

The communities, clans, nations and tribes we call Indigenous peoples are just that: Indigenous to the lands they inhabit, in contrast to and in contention with the colonial societies and states that have spread out from Europe and other centres of empire. It is this oppositional, place-based existence, along with the consciousness of being in struggle against the dispossessing and demeaning fact of colonisation by foreign peoples, that fundamentally distinguishes Indigenous peoples from other peoples of the world (Alfred and Corntassel 2005, p. 597). ${ }^{6}$

It is critical to note not only how Indigenous peoples define their identity, but also what they call themselves. We consider it both an academic responsibility and an honour, in this special issue, to use Indigenous tribal names in their languages as a point of reference that precede the names assigned to them and their territories by modern nation states.

While we and our contributing authors are concerned with historic and continuing threats to Indigenous peoples and lifeways, ${ }^{7}$ it is not solely or even primarily

\footnotetext{
${ }^{3}$ UNPFII (United Nations Permanent Forum on Indigenous Issues) (2006). Indigenous peoples, Indigenous voices. Factsheet. New York: UNPFII. Retrieved 3 January 2018 from https://www.un.org/esa/ socdev/unpfii/documents/5session_factsheet1.pdf.

${ }^{4}$ McCarty, T.L., \& Coronel-Molina, S.M. (2017). Language education planning and policy by and for Indigenous peoples. In T.L. McCarty \& S. May (Eds), Language policy and political issues in education (pp. 155-170). Cham: Springer International.

${ }^{5}$ UN (United Nations) (n.d.). Indigenous peoples at the UN [dedicated United Nations webpage]. Retrieved 3 January 2018 from https://www.un.org/development/desa/indigenouspeoples/about-us.html.

${ }^{6}$ Alfred, T. \& Corntassel, J. (2005). Being Indigenous: Resurgences against contemporary colonialism. In R. Bellamy (Ed.), The politics of identity-IX (pp. 597-614). Oxford, UK: Government and Opposition Ltd.

7 The term lifeway refers to "a way through life, a course of life; a way or manner of life, (in later use) especially one that is customary or traditional" (OED n.d., emphasis added). In Indigenous terms, lifeways also refer to the intersecting elements that make life possible within local ecologies and with global implications. For example, Indigenous lifeways include the intersection of languages, environments, cultural practices, economies and knowledge sharing and transmission. OED (Oxford English Dictionaries) (n.d.). Definition of lifeway in English. In Oxford English dictionary [online resource]. Retrieved 3 January 2019 from https://en.oxforddictionaries.com/definition/lifeway.
} 
through opposition that Indigenous peoples are identified. Rather, this special issue seeks to critically examine and valorise the diversity and distinctiveness of Indigenous sustainabilities ${ }^{8}$ through the lens of education as related to environment, natural resources, knowledge production, languages and cultural practices. The link between Indigenous languages, cultural practices, environmental knowledge and biodiversity is well-documented (Maffi and Woodley 2010). ${ }^{9}$ As Daniel Nettle and Suzanne Romaine point out in their global examination of these connections, "areas which are rich in languages also tend to be rich in biodiversity value" (Nettle and Romaine 2000, p. 43). ${ }^{10}$ These connections are foundational to our understanding of Indigenous knowledge systems, and situated analyses of those connections weave throughout the special issue.

In the remainder of this introduction we discuss Indigenous knowledge systems in greater depth, including the theories of sustainability, learning and teaching those knowledge systems reflect and promote. We then situate current conditions of vulnerability within postcolonial critiques of Western modernity and the legacy of colonial schooling. As we show, those conditions "have clear continuities with the settler project and strategies of [Indigenous] elimination" (Grande 2018, p. 169). Yet, amidst this historical legacy, Indigenous peoples continue to protect and develop vital communities, land-based cultural practices, languages, and ways of knowing and being, examples of which are layered throughout this introduction and the feature articles that follow. To fully illuminate those efforts, we argue for the need for Indigenous scholarship and self-representation. We conclude by introducing the authors whose work is featured in this special issue, and the contributions of their scholarship to our version of Nelly Stromquist and Karen Monkman's (2000) question with which we began: What purposes will education serve in this current era when Indigenous peoples are experiencing increased threats to sustainability, including our lifeways?

\section{The politics of knowledge, place and being}

From the early 1990s until his passing in 2011, Yupiaq ${ }^{11}$ scholar and educator Angayuqaq Oscar Kawagley's research and community-based work on Alaska Native ways of knowing brought significant regional and international attention to the relationship between environmental issues and Indigenous epistemologies and

\footnotetext{
8 We use the term sustainabilities in the same way that we use knowledges - to describe the multiple ways and approaches, in which Indigenous peoples are conceptualising and promoting sustainability in the context of distinctive homelands and linguistic and cultural ecologies, and local relationships with those homelands.

9 Maffi, L., \& Woodley, E. (2010). Biocultural diversity conservation: A global sourcebook. London, UK: Earthscan.

${ }^{10}$ Nettle, D., \& Romaine, S. (2000). Vanishing voices: The extinction of the world's languages. Oxford, UK: Oxford University Press.

11 The Yupiaq people are Indigenous to the western and southwestern regions of what is now known as the US state of Alaska.
} 
pedagogies (see, e.g., Kawagley 1990, 1995) ${ }^{12}$. Describing situated applications of science and technology that have sustained Alaska Native peoples in the circumpolar North for millennia, he argued that Indigenous peoples are consistently in relation with the natural world as observers and scientists. But, as suggested by the subtitle of his seminal book, A Yupiaq Worldview: A Pathway to Ecology and Spirit (Kawagley 1995), he offered an important caveat - the recognition of values and spirit. Writing with his long-time collaborator Ray Barnhardt, Kawagley noted:

For Indigenous people there is a recognition that many unseen forces are at play in the elements of the universe and that very little is naturally linear, or occurs in a two-dimensional grid or a three-dimensional cubic form. Indigenous people are familiar with the notions of energy conservation, irregularities in patterns and anomalies of form and force. Through long observation they have become specialists in understanding the interconnectedness and holism of our place in the universe (Barnhardt and Kawagley 2005, p. 12). ${ }^{13}$

Similarly, Anthony Bebbington's (1990) ${ }^{14}$ advocacy of "farmer knowledge" in the 1980s and 1990s acknowledged the millennia of local Indigenous agro-ecological knowledge abundant in the Andes of South America. At the same time, scholars like Bebbington raised the alarm regarding significant human-made changes resulting from industries such as extractive development, which have actually increased recently, causing concern regarding how Indigenous peoples and their knowledges can respond to local and global catastrophes.

Yet, rather than subscribe to crisis narratives, we and our contributing authors seek to expand our understanding of Indigenous knowledges through deep examination of the theories they encapsulate and enact through linguistic and cultural practices. For example, Hopi ${ }^{15}$ scholar Sheilah Nicholas draws on the Hopi Emergence story to recount a teaching from oral tradition that she regards as the Hopi theory of life: "Itam il hita ane lumalat qatsit namortota. Yaw son haq Hopit qatsiyat sòosok aw su'laqewni" or "We [as a people] chose this difficult life of hard work and struggle [at emergence]. It is said that no others would willingly commit to this way of

\footnotetext{
${ }^{12}$ Kawagley, A.O. (1990). Yup'ik ways of knowing. Canadian Journal of Native Education, 17(2), 5-17.

Kawagley, A.O. (1995). A Yupiaq worldview: A pathway to ecology and spirit. Prospect Heights, IL: Waveland Press.

${ }^{13}$ Barnhardt, R., \& Kawagley, A.O. (2005). Indigenous knowledge systems and Alaska Native ways of knowing. Anthropology and Education Quarterly, 36(1), 8-23.

${ }^{14}$ Bebbington, A. (1990). Farmer knowledge, institutional resources and sustainable agricultural strategies: A case study from the eastern slopes of the Peruvian Andes. Bulletin of Latin American Research, 9(2), 203-228.

${ }^{15}$ According to Nicholas, "The Hopi people, Hopìit, are the westernmost of the Puebloan peoples in the U.S. Southwest and continue to reside in village communities on their Aboriginal lands in the Black Mesa Plateau region of the state of Arizona" (Nicholas 2019, p. 174). Nicholas, S.E. (2019). "Without the language, how Hopi are you?": Hopi cultural and linguistic identity construction in contemporary linguistic ecologies. In T.L. McCarty, S.E. Nicholas \& G. Wigglesworth (Eds), A world of Indigenous languages: Politics, pedagogies and prospects for language reclamation (pp. 173-193). Bristol, UK: Multilingual Matters.
} 
life" (Nicholas 2010, p. 138). ${ }^{16}$ In parallel work published elsewhere, Wanka/Quechua $^{17}$ scholar Elizabeth Sumida Huaman (2019) ${ }^{18}$ examines yachayninchis or "our knowledge" in the Peruvian Andes as embodying values and instructions for how to live in the Andean world, including remaining in dialogue with the natural world on a daily basis: "Pachamamanchiswanqa rimananchispuni sapa p'unchay." These examples of Indigenous scholarship demonstrate the importance of Indigenous testimonies regarding land epistemologies and pedagogies and the recentring of Indigenous oral traditions, what Stó:lo ${ }^{19}$ scholar Jo-ann Archibald (2008) ${ }^{20}$ calls "storywork": experiential narratives that constitute epistemic, theoretical, pedagogical and empirical lenses through which relationships with and between people and the natural world can be understood. "[O]ur stories are our theories", Lumbee ${ }^{21}$ scholar Bryan McKinley Jones Brayboy reminds us, and "serve as the basis for how our communities work" (Brayboy 2005, p. 427). ${ }^{22}$

Mvskove Creek ${ }^{23}$ scholar K. Tsianina Lomawaima $(1999)^{24}$ differentiates this form of knowledge and theory-building - which she posits as central to Indigenous self-education or "local education" - from knowledge privileged in "the post-industrial schooling complex" (Lomawaima 2015, p. 365). ${ }^{25}$ "Indigenous educational systems are rooted in key cultural precepts and practices and refined over generations", she notes; they are "traditional but not static or unchanging", diverse, distinctive, and designed to accomplish a fundamental task: "surviving over time through the

\footnotetext{
16 Nicholas, S.E. (2010). Language, epistemology, and cultural identity: "Hopiqatsit aw unangvakiwyungwa" ("They have their heart in the Hopi way of life"). American Indian Culture and Research Journal, 34(2), 125-144.

17 Quechua are diverse Indigenous peoples whose homelands are located in present-day Colombia, Ecuador, Peru, Bolivia, Chile and Argentina. Wanka are a related Quechua people whose ancestral homelands are in the region of Junín, Peru.

18 Sumida Huaman, E. (2019). Yachayninchis (our knowledge): Agriculture, environment, and human rights education in the Peruvian Andes. In E. McKinley \& L.T. Smith (Eds), Handbook of Indigenous education (pp. 1-41). Singapore: Springer.

19 The Stó:lo Nation is a First Nations people indigenous to what is now known as the province of British Columbia, Canada.

20 Archibald, J. (2008). Indigenous storywork: Educating the heart, mind, body, and spirit. Vancouver, BC: UBC Press.

21 Lumbee scholar Malinda Maynor Lowery notes that the people known today as Lumbee have also been called Croatan, Cherokee, Siouan and Tuscarora. "[A]ll belong to land around the Lumber River and the town of Pembroke in Robeson County, North Carolina [USA]" (Lowery 2010, p. xi). Lowery, M.M. (2010). Lumbee Indians in the Jim Crow South: Race, identity, and the making of a nation. Chapel Hill, NC: University of North Carolina Press.

22 Brayboy, B.M.J. (2005). Toward a tribal critical race theory in education. The Urban Review, 37(5), 425-456.

23 Mvskove (also spelled Muscogee) homelands and the Muscogee (Creek) Nation are located in present-day Oklahoma, USA.

${ }^{24}$ Lomawaima, K.T. (1999). The unnatural history of American Indian education. In K.G. Swisher \& J.W. Tippeconnic III (Eds), Next steps: Research and practices to advance Indian education (pp. 3-31). Charleston, WV: Clearinghouse on Rural Education and Small Schools.

${ }^{25}$ Lomawaima, K.T. (2015). Education. In R. Warrior (Ed.), The world of Indigenous North America (pp. 365-387). New York: Routledge.
} 
production of healthy, functional, caring individuals committed to a shared way of life" (ibid., p. 366).

Throughout the world there are abundant examples of the ways in which Indigenous self-education is being reclaimed, revitalised and sustained by individuals, communities and non-Indigenous allies. In Aotearoa/New Zealand and what is now the United States (US) state of Hawai'i, Māori and Kanaka Maoli (Native Hawaiian) communities have been at the forefront of this work, beginning with parent-run Kōhanga Reo and Pūnana Leo "language nest" preschools in the early 1980s, and continuing with the Indigenous language- and culture-based education systems that now extend from preschool to graduate school (Iokepa-Guerrero 2016; Rau et al. 2019; Wilson and Kamanā 2006; Wong 2011). ${ }^{26}$ Māori and Kanaka Maoli scholarship around mental decolonisation in order to restructure educational systems (Smith 2003) ${ }^{27}$ and land-based educational practices and reclamations (Goodyear$\mathrm{Ka}$ 'ōpua 2013 ${ }^{28}$ have inspired Indigenous communities worldwide to rethink how Indigenous knowledges can reframe educational design.

Even earlier, struggles between Kanienkehaka (Mohawk) ${ }^{29}$ peoples and Canadian and US settler governments gave birth to Native-run Survival and Freedom schools on both sides of the settler-imposed international border along the St. Lawrence River. These education initiatives continue today as "community-wide effort[s] in cultural and linguistic revitalization" (White 2015, p. 176). ${ }^{30}$ Importantly, these efforts have taken place alongside a movement to reclaim Kanienkehaka lands and land-based cultural practices to counter industrial polluters. For example, a community-based self-education initiative at Akwesasne in what is now upstate New York pairs learner-apprentices "with master knowledge-holders to learn traditional, landbased cultural practices" such as hunting, trapping, use of medicinal plants, fishing,

\footnotetext{
${ }^{26}$ Iokepa-Guerrero, N. (2016). Revitalization programs and impacts in the USA and Canada. In S.M. Coronel-Molina \& T.L. McCarty (Eds), Indigenous language revitalization in the Americas (pp. 227246). New York: Routledge.

Rau, C., Murphy, W., \& Bird, P. (2019). The impact of "culturalcy" in Ngā Kura ā Iwi tribal schools in Aoetearoa/NZ: Mõ tātou, mā tātou, e ai ki a tātou - For us, by us, our way. In T.L. McCarty, S.E. Nicholas, \& G. Wigglesworth (Eds), A world of Indigenous languages: Politics, pedagogies, and possibilities for language reclamation (pp. 69-90). Bristol, UK: Multilingual Matters.

Wilson, W.H., \& Kamanā, K. (2006). "For the interest of the Hawaiians themselves": Reclaiming the benefits of Hawaiian-medium education. Hülili: Multidisciplinary Research on Hawaiian Well-Being, 3(1), 153-178.

Wong, K.L. (2011). Keynote address. Language, fruits and vegetables. In M.E. Romero-Little, S.J. Ortiz, T.L. McCarty, \& R. Chen (Eds), Indigenous languages across the generations - Strengthening families and communities (pp. 3-16). Tempe, AZ: Arizona State University Center for Indian Education.

27 Smith, G.H. (2003). Indigenous struggle for the transformation of education and schooling. Keynote address to the Alaskan Federation of Natives (AFN) Convention in Anchorage, Alaska, USA, October. Retrieved 2 December 2005 from http://www.ankn.uaf.edu/curriculum/Articles/GrahamSmith.

28 Goodyear-Ka'ōpua, N. (2013). The seeds we planted: Portraits of a Native Hawaiian charter school. Minneapolis, MN: University of Minnesota.

29 The Kanienkehaka (Mohawk) people are Haudenosaunee Indigenous peoples whose homelands span the northeastern United States and into Canada. For more information on Mohawk histories, see: http:// www.korkahnawake.org [accessed 7 January 2018].

${ }^{30}$ White, L. (2015). Free to be Mohawk: Indigenous education at the Akwesasne Freedom School. Norman, OK: University of Oklahoma Press.
} 
water use, horticulture and basket making (Alfred 2014, p. 135). ${ }^{31}$ Mohawk scholar Taiaiake Alfred notes that "transmission of [the Mohawk] language and important technical focal vocabulary embedded in traditional resource harvesting practices are an important aspect in ... restoring health and vitality of the people" (ibid., pp. 142-43).

Likewise, the articles in this issue of the journal link Indigenous knowledge systems with education to address a breadth of challenges and responses to sustainability, drawing on Indigenous theories and comparative-international perspectives. In this special issue, we conceive of education as a critical intervention to sustaining Indigenous lifeways by confronting and transforming Western models of education imposed on Indigenous peoples in the Global North and Global South. In so doing, we think from and for places, experiences, temporalities and life projects commonly negated or misrepresented in dominant education. As such, our contributing authors examine the ways in which they and their communities are framing Indigenous knowledges to promote lifelong learning. The articles engage a larger discourse on education for and by Indigenous and other non-dominant communities, including Indigenous appropriations of state-controlled education systems through culturally sustaining and revitalising pedagogies (Lee and McCarty 2017) ${ }^{32}$; the links between land, natural resources and Indigenous sovereignty (Stark and Stark 2018) ${ }^{33}$; distinctive cultural practices within Indigenous ecologies and traditional ecological knowledge (TEK); Indigenous environmental intersections with science (Bang et al. $2018)^{34}$; and topics such as language education policy, cultural and language revitalisation, critical youth studies and intergenerational learning.

\section{Postcolonialism, coloniality and modernity as a "death project"}

To fully understand the politics of knowledge and being, it is essential to situate contemporary issues in education within legacies of colonial imperial projects that have been imposed on peoples and places all over the globe. In this regard, the field of postcolonial studies provides conceptual tools to broadly address the continued impacts and legacies of colonialism. ${ }^{35}$ Even as the era of political colonial

\footnotetext{
31 Alfred, T. (2014). The Akwesasne cultural restoration program: A Mohawk approach to land-based education. Decolonization: Indigeneity, Education and Society, 3(3), 134-44.

32 Lee, T.S., \& McCarty, T.L. (2017). Upholding Indigenous education sovereignty through critical culturally sustaining/revitalizing pedagogy. In D. Paris \& H.S. Alim (Eds), Culturally sustaining pedagogies: Teaching and learning for justice in a changing world (pp. 61-82). New York: Teachers College Press.

33 Stark, H.K., \& Stark, K.J. (2018). Nenabozho goes fishing: A sovereignty story. Daedalus, Journal of the American Academy of Arts and Sciences, 147(2), 17-26.

34 Bang, M., Marin, A., \& Medin, D. (2018). If Indigenous peoples stand with the sciences, will scientists stand with us? Daedalus, Journal of the American Academy of Arts and Sciences, 147(2), 148-159.

35 The term/notion of postcolonialism emerged during and after global uprisings against colonial imperialism when various intellectual and academic communities challenged the West's long-standing claim to be a totalising epistemic framework. Emerging in the 1960s, these debates instigated the development of sets of theoretical and conceptual tools by literary and cultural studies scholars, which eventually came to inform the humanities and social sciences, including education.
} 
imperialism has ended, those legacies challenge us to critically engage with and problematise how the modern Western world-system relied upon exploitative colonial-capitalist relations for its own self-aggrandisement, the quintessential link between modernity and colonialism, or what Walter Mignolo $(1992,2000)^{36}$ deems the inextricable "modern/colonial" meta-narrative of the West and the modern world system.

Aligning postcolonial approaches with Indigenous critiques of Western modernity and following the lead of the Nasa Indigenous people in Colombia, Julia SuárezKrabbe (2012) $)^{37}$ argues that we may conceive of Eurocentric modernity as a "death project" closely linked to capitalism and coloniality. The death project describes the systemic ways in which coloniality works against life and the heterogeneity that life depends upon - including war, genocide, epistemicide, the continued attacks waged against nature, and the commodification and patenting of life (as in water or seeds). Coloniality, in turn, is a specific connectedness between racism, capitalism and patriarchy generated through the processes of domination that became globalised in the wake of colonialism and remain intact today (Quijano 2008). ${ }^{38}$ Coloniality and the death project are, according to Suárez-Krabbe, two sides of the same coin. While coloniality describes how the historically constituted global system works, the death project speaks about what it does in terms of practices and consequences. Education can be conceived as central to both.

\section{Colonial education}

Colonial education was central to providing the "rational" link between racism, capitalism and patriarchy, and to making this rationality the norm, spreading it as a universal truth. As part of the death project, education was pivotal to epistemicides around the globe, and worked as an important tool of segregation and exclusion. The repression or destruction of a peoples' cultural life was central to colonial domination, or, as noted by Amilcar Cabral in the context of Portuguese colonial imperialism in African territories,

the colonizer not only creates a system to repress the cultural life of the colonized people, he also provokes and develops the cultural alienation of a part of the population, either by assimilation of indigenous people or by creating a

\footnotetext{
36 Mignolo, W. D. (1992). The darker side of the Renaissance: Colonization and the discontinuity of the classical tradition. Renaissance Quarterly, 45(4), 808-828.

Mignolo, W. D. (2000) Local histories/global designs: Coloniality, subaltern knowledges, and border thinking. Princeton, NJ: Princeton University Press.

37 Suárez-Krabbe, J. (2012). Identity and the preservation of being. Social Identities, 8(3), 335-353.

38 Quijano, A. (2008). Coloniality of power, Eurocentricism, and social classification. In M. Moraña, E.D. Dussel, \& C.A. Jáuregui (Eds), Colonialism and its replicants: Coloniality at large - Latin America and the postcolonial debate (pp. 181-224). Durham, NC: Duke University Press.
} 
social gap between indigenous, elite, and popular masses (Cabral 1982 [1971], p. 45$).^{39}$

The primary aim of colonial education was to domesticate or transform Indigenous populations from their "primitive" ways while preparing them for work in a servile class. Elsewhere, K. Tsianina Lomawaima and Teresa McCarty have described this as "erase and replace": "Erase Native languages, replace with English. Erase Native religions; replace with Christianity. And so on" (Lomawaima and McCarty 2006, pp. xxii). ${ }^{40}$

A global history of colonial education systematically apprehends "the paradoxical nature of the globalization process, the dialectic in the complexity of world relations and the diversity of assimilation logic, worldwide diffusion and the indigenous, culturally dependent reception of homogenization and pluralization" (Bagchi et al. 2014, p. 21). ${ }^{41}$ In sub-Saharan Africa, for instance, what Gikuyu ${ }^{42}$ scholar Ngũgĩ wa Thiong'o calls linguicide - "the linguistic equivalent of genocide" (Ngũgĩ wa Thiong'o 2009, p. 17) ${ }^{43}$ - was part of a larger colonial project to deculturise and deterritorialise African peoples "through the exclusive use of colonial languages in high-prestige domains" - including schooling (Makalela 2005, p. 153; see also Skutnabb-Kangas and Dunbar 2010). ${ }^{44}$ Under late Portuguese colonialism during the latter half of the 20th century, colonial education systems in territories such as Mozambique and Angola aimed to "nationalise" Indigenous communities. James Duffy observed that education was assimilationist to the extent that it could be used to subdue resistance to Portuguese rule. As the author noted, "the design of the Salazar [late 20th-century colonial] regime was to see to it that the African majority does not become any more politically conscious than its metropolitan rural majority" and led to "the formation of a devout, semi-literate and conservative African population" (Duffy 1961, p. 301). ${ }^{45}$ Thus, education was designed to uphold apartheid through

\footnotetext{
39 Cabral, A. (1982 [1971]). Portugal is not an imperialist country. In A. de Bragança. \& I. Wallerstein (Eds), The African liberation reader: Documents of the national liberation movements. Vol. 1: The anatomy of colonialism (pp. 31-34). London: Zed Press.

${ }^{40}$ Lomawaima, K.T., \& McCarty, T.L. (2006). "To remain an Indian": Lessons in democracy from a century of Native American education. New York: Teachers College Press.

41 Bagchi, B., Fuchs E., \& Rousmaniere, K. (2014) Connecting histories of education: Transnational and cross-cultural exchanges in (post)colonial education. New York: Berghahn Books.

42 The Gikuyu people (also Kikuyu/Agīkuyu) are native to the modern state of Kenya.

43 Ngũgĩ wa Thiong'o (2009). Something torn and new: An African renaissance. New York: BasicCivitas Books.

44 Makalela, L. (2005). "We speak eleven tongues": Reconstructing multilingualism in South Africa. In B. Brock-Utne \& R.K. Hopson (Eds), Languages of instruction for African emancipation: Focus on postcolonial contexts and considerations (pp. 147-174). Cape Town, South Africa/Dar es Salaam, Tanzania: Center for Advanced Studies of African Society (CASAS)/Mkuki na Nyota Publishers.

Skutnabb-Kangas, T., \& Dunbar, R. (2010). Indigenous children's education as linguistic genocide and a crime against humanity? A global view. Gáldu Č́la. Journal of Indigenous Peoples' Rights, 1, entire issue.

45 Duffy, J. (1961). Portuguese Africa (Angola and Mozambique): Some crucial problems and the role of education in their resolution. The Journal of Negro Education, 30(3), 294-301.
} 
the creation of separate rudimentary schooling for "indigenous" people and secondary schooling for White and "assimilated" colonists (Saúte 2004). ${ }^{46}$

In Canada and the United States, colonial education was explicitly assimilationist from the 17th throughout most of the 20th century. In both of these settler states, Native children were forcibly taken from their families to residential schools far from their homes, where they were severely punished for "Indian talk" (Spack 2002, p. 24; see also Lomawaima and McCarty 2006; Reyhner and Eder 2004). ${ }^{47}$ Australia's British colonial government applied tactics of isolation and assimilation with a "White Australia" policy intended "to 'breed out' [Aboriginal peoples'] black traits" in order to "produce a homogeneous English-speaking Anglo-Saxon culture" (Romaine 1991, p. 3). ${ }^{48}$ Known today as the "stolen generation", Aboriginal and Torres Strait Islander children were also forcibly taken from their homes and sent to faraway schools. This often occurred "in the absence of the parent but sometimes even by taking the child from the mother's arms" (Commonwealth of Australia 1997, p. 4). ${ }^{49}$ In Latin America, a clear "intention of eradicating Indigenous ethnocultural differences" underlay centuries of policies designed to configure a uniform "national" society through segregated subtractive schooling (López 2008, p. 43). ${ }^{50}$ In each of these contexts, Indigenous children were prevented from learning their ancestral language and often suffered physical and psychological abuse.

Colonial education was also implemented with the Saami (Sámi) peoples, whose lands stretch across what is now northern Finland, northern Norway, Sweden, as well as the Kola Peninsula of Russia. One strand of the roots of this education policy can be traced to Sweden's policy of official colonisation of Sápmi (Saamiland), beginning in 1673 (Kvist 1998). ${ }^{51}$ From the 17th century onwards, education served the purpose of domesticating the Saami, starting with the Church of Sweden's missionising efforts (Lindmark 2014). ${ }^{52}$ In mid-19th century Norway, Saami children

\footnotetext{
46 Saúte, A. R. (2004) Escolas de Habilitação de Professores Indígenas "José Cabral”, Manhiça-Alvor: Subsídios para o Estudo da Formação da Elite Instruída em Moçambique (1926-1974) ["José Cabral” Indigenous teacher training schools, Manhiça-Alvor: Subsidies for the study of instructed elite training in Mozambique (1926-1974)]. Maputo: Promédia .

47 Spack, R. (2002). America's second tongue: American Indian education and the ownership of English, 1860-1900. Lincoln, NE: University of Nebraska Press.

Reyhner, J., \& Eder, J. (2004). American Indian education: A history. Norman, OK: University of Oklahoma Press.

48 Romaine, S. (1991). Introduction. In S. Romaine (Ed.), Language in Australia (pp. 1-24). Cambridge, UK: Cambridge University Press.

${ }^{49}$ Commonwealth of Australia (1997). Bringing them home: Report of the national inquiry into the separation of Aboriginal and Torres Strait Islander children from their families. Sydney: Human Rights and Equal Opportunity Commission.

${ }^{50}$ López, L.E. (2008). Top-down and bottom-up: Counterpoised visions of bilingual intercultural education in Latin America. In N.H. Hornberger (Ed.), Can schools save Indigenous languages? Policy and practice on four continents (pp. 42-65). New York: Palgrave Macmillan.

51 Kvist, R. (1998). The racist legacy in modern Swedish Saami policy. Canadian Journal of Native Studies, 14(2), 203-220).

52 Lindmark, D. (2014). Colonial education and Saami resistance in early modern Sweden. In B. Bagchi, E. Fuchs, \& K. Rousmaniere (Eds), Connecting histories of education. Transnational and cross-cultural exchanges in (post) colonial education (pp. 140-155). New York: Berghahn Books.
} 
were punished for speaking Saami, and their teachers were paid extra to monitor the parents' language use. Ole Henrik Magga and Tove Skutnabb-Kangas refer to the period between 1870 to 1970 as the "dark century" in Norwegian policy towards Saami peoples - a "harsh assimilation phase ... [that] had detrimental effects" (Magga and Skutnabb-Kangas 2003, pp. 40-41). ${ }^{53}$

A global history of colonial education excavates experiences of ethnocide, linguicide, repression and resistance while at the same time illustrating the transcultural exchanges and transformations that arose as a result of these relationships (see, e.g., Bagchi et. al. 2014; Lomawaima 2018). ${ }^{54}$ This is both the legacy and the ongoing reality within contemporary education, as settler colonialism and coloniality continue to frame relations of power today. The anthropologist Patrick Wolfe sums up the patterns of settler colonialism: "The colonizers came to stay", making invasion "a structure, not an event" (Wolfe 1999, p. 2). ${ }^{55}$ As Eve Tuck and K. Wayne Yang further observed: “. . . the colonizers arrive at a place ('discovering' it) and make it a permanent home (claiming it) ... The settler colonial state is dependent on destroying and erasing Indigenous inhabitants in order to clear them from valuable land" (Tuck and Yang 2014, p. 224). ${ }^{56}$ Core elements of that structure are state-level policies of ethnocide and linguicide, largely through assimilative schooling.

Inasmuch as capitalism is one of the elements of systemic domination in coloniality, it is important to underline how coloniality is productive. As Dip Kapoor $(2009)^{57}$ has argued, early colonial contact must be distinguished from modern European capitalist colonialism, which produced the growth of European industry and capitalism while restructuring colonised economies. Moreover, in addition to material emasculation, modern European capitalist colonialism is both formation and operation of discourse where colonial subjects are made, which includes the erasure of Indigenous knowledges and connections to land: Thus, the "chronological, material and spatio-temporal invasiveness of modern European capitalist colonialism demands persistent material, cultural and ideological scrutiny... in the interests of decolonization and inversions of the inequities of colonialism" (Kapoor 2009, p. 5). The question for Indigenous education scholars then becomes how struggles in and through education, which define matters of sustainability and the futurity of Indigenous peoples - and by extension all peoples - depart from these legacies and contribute to the interrogative processes that Kapoor proposes. Applying the lens of

\footnotetext{
53 Magga, O.H., \& Skutnabb-Kangas, T. (2003). Life or death for languages and human beings: Experiences from Saamiland. In L. Huss, A. C. Grima, \& K.A. King (Eds), Transcending monolingualism: Linguistic revitalization in education (pp. 35-52). New York: Routledge.

${ }^{54}$ Lomawaima, K.T. (Ed.) (2018). Native American boarding school stories. Journal of American Indian Education, 57(1), special issue.

55 Wolfe, P. (1999). Settler colonialism and the transformation of anthropology: The politics and poetics of an ethnographic event. London: Cassell.

56 Tuck, E., \& Yang, K.W. (2014). R-words: Refusing research. In D. Paris \& M.T. Winn (Eds), Humanizing research: Decolonizing qualitative inquiry with youth and communities (pp. 223-247). Los Angeles, CA: SAGE.

57 Kapoor, D. (2009). Education, decolonization and development: Perspectives from Asia, Africa and the Americas. In Kapoor, D. (Ed.), Education, decolonization and development: Perspectives from Asia, Africa and the Americas (pp. 1-6). Rotterdam: Sense.
} 
decoloniality, for instance, Paiute ${ }^{58}$ scholar Miye Tom and colleagues $(2017)^{59}$ argue that research must centralise the knowledges and realities commonly portrayed as absent in order to openly challenge dominant (colonial) knowledge construction and to transgress boundaries and borders that continue to reproduce coloniality at local, national and global levels (e.g., "North" and "South" binaries).

\section{The "life project": Indigenous knowledges and education}

Indigenous communities have persevered under processes of colonisation and statesanctioned efforts and programmes that sought to eradicate them physically, territorially, epistemically, culturally and linguistically. Despite these acts of violence, as we have shown, Indigenous knowledges have been reclaimed and sustained by Indigenous peoples in diverse regions around the world. Furthermore, important international recognition has been achieved over the past several decades in the arena of Indigenous rights, which include the right of Indigenous peoples to protect, maintain and revitalise Indigenous knowledge systems. Indigenous knowledge systems and their manifestations, including traditional ecological knowledge, farmer knowledge, and other forms of ecological knowledge have served local populations for generations by facilitating thoughtful and deliberate human-environmental interactions leading to what is broadly referred to as environmental sustainability (Barnhardt and Kawagley 2005; Bebbington 1990; McGregor 2004; Simpson 2002, 2014). ${ }^{60}$

International agencies have also recognised the urgency of working with Indigenous peoples towards this goal. In the United Nations Declaration on the Rights of Indigenous Peoples (UNDRIP), the UN General Assembly observed that "respect for indigenous knowledge, cultures and traditional practices contributes to sustainable and equitable development and proper management of the environment" (UN 2007, p. 2). ${ }^{61}$ In the present decade, Indigenous communities have sought to make political and legal strides that assert rights to self-determination, governance, land, knowledges and languages, environment and development, and education. In September 2014, a UN resolution included a commitment "to respect[ $\mathrm{t}$ ] the contributions of

\footnotetext{
58 The Paiute people are Indigenous to the Great Basin region of the US, including the present-day states of California, Nevada, Oregon, Idaho, Arizona and Utah. For more information on Tom's Nevada Paiute affiliation, see: https://www.wrpt.org/ [accessed 7 January 2019].

59 Tom, M.N., Suárez-Krabbe, J., \& Caballero Castro, T. (2017). Pedagogy of absence, conflict, and emergence: Contributions to the decolonization of education from the Native American, Afro-Portuguese, and Romani experiences. Comparative Education Review, 61(S1), S121-S145.

60 McGregor, D. (2004). Coming full circle: Indigenous knowledge, environment, and our future. American Indian Quarterly, 28(3/4), 385-410.

Simpson, L. (2002). Indigenous environmental education for cultural survival. Canadian Journal of Environmental Education, 7(1), 13-25.

Simpson, L. (2014). Land as pedagogy: Nishnaabeg intelligence and rebellious transformation. Decolonization: Indigeneity, Education and Society, 3(3), 1-25.

61 UN (United Nations) (2007). Declaration on the rights of Indigenous peoples. A/'RES/62/295, adopted by the United Nations General Assembly on 13 September 2007. New York: United Nations.
} 
indigenous peoples to ecosystem management and sustainable development" (UN 2014, p. 5). ${ }^{62}$

The question we ask, however, is how these contributions may be addressed in a manner that creates and protects spaces of "Indigenous self-representation" (Smith $2012)^{63}$ where Indigenous peoples address their own problems, claim and reclaim their rights. Indigenous peoples navigate a complex social and political landscape in this regard. On the one hand, the increasing recognition and support from international organisations and agencies are the fruit of Indigenous peoples' struggles to persevere and protect life. On the other hand, Indigenous peoples are often reduced to what Astrid Ulloa (2004) ${ }^{64}$ has called the "ecological Native", that is, a specific, neo-colonial stereotype similar to the caricature of the "noble savage". As "ecological Natives", Indigenous peoples are expected to make specific claims (defence of nature), have specific features ("traditional" dress, lack of technology, lack of formal education), and live in specific conditions (rural areas). In addition, the ecological Native is the source for epistemic extractivism. In this way, the self-representation of Indigenous peoples, their criticisms and claims beyond the logic that fits the "ecological Native" (thereby protecting the settler state) is intentionally viewed as absent, implying that systemic change is foreclosed. As Philip Deloria declared, "It is critical, then, that we question expectations and explore their origins, for they created - and they continue to reproduce - social, political, legal and economic relations that are asymmetrical, sometimes grossly so" (Deloria 2004, p. 4). ${ }^{65}$

Beyond the discourse of sustainability - against the death project and towards a life project - scholar Mark Ericson has also drawn attention to Indigenous ecological survivance, building on Vizenor's original proposal (Ericson 2017; cf. Vizenor 1994), ${ }^{66}$ and he considers how Indigenous peoples, and specifically youth, protect, preserve and promote their environments through practices of nurturing integral to their cultures that are also adapting to current social and environmental challenges. In the context of biocultural diversity (Maffi 2001; Maffi and Woodley 2010), ${ }^{67}$ we are seeing not only that Indigenous peoples work to protect their communities and

\footnotetext{
${ }^{62}$ UN (United Nations) (2014). Outcome document of the high-level plenary meeting of the General Assembly known as the World Conference of Indigenous Peoples (22 September 2014). Resolution 69/2. New York: United Nations. Retrieved 22 September 2018 from https://undocs.org/en/A/RES/69/2.

${ }^{63}$ Smith, L. (2012). Decolonizing methodologies: Research and Indigenous peoples (2nd edn). London: Zed Books.

${ }^{64}$ Ulloa, A. (2004). La construccióńn del nativo ecológico. Complejidades, paradojas y dilemas de la relación $n$ entre los movimientos indígenas y el ambientalismo en Colombia [The construction of the ecological Native. Complexities, paradoxes and dilemmas in the relationship between Indigenous movements and environmental movements in Colombia]. Bogotá: Instituto Colombiano de Antropología e Historia Colciencias.

65 Deloria, P.J. (2004). Indians in unexpected places. Lawrence, KS: University Press of Kansas.

66 Ericson, M. (2017). Indigenous ecological survivance: Youth in community and cultural sustainability. In E. Sumida Huaman \& B.M.J. Brayboy (Eds), Indigenous innovations in higher education: Local knowledge and critical research (pp. 195-217). Rotterdam: Sense.

Vizenor, G. (1994). Manifest manners: Narratives on postindian survivance. Lincoln, NE: University of Nebrasca Press.

67 Maffi, L. (2001). On biological diversity: Linking language, knowledge, and the environment. Washington, DC: Smithsonian Institution.
} 
cultures to ensure the continuity of their ways of life, but also how they are engaged in this work and, moreover, what we can learn from each other to ensure survival for all beings. In this respect, there is an urgent need to engage Indigenous perspectives in research at local, national and international levels.

\section{Challenging dominant paradigms in education: Indigenous research in global dialogue}

In recent decades, Indigenous peoples have reframed dominant discourses of development and globalisation while challenging colonially entrenched neoliberal forms of oppression evident in economic and environmental exploitation of Indigenous lands. However, as the colonial enmeshment of the field of international and comparative education has become a contentious subject of discussion (Takayama et al. 2016), ${ }^{68}$ the perspectives of Indigenous peoples remain largely underrepresented. This special issue addresses this gap in knowledge and Indigenous representation, tackling global forces of domination by imperialism (e.g. European, North American) and the enduring effects of colonialism within the colonial/imperial "Global North", while confronting its legacy and contemporary reality of (White) settler colonialism (Wolfe 1999, 2006). ${ }^{69}$

The work of the Indigenous scholars presented here surpasses the global segregationist structures of knowledge by bridging global North-South divides to address common yet locally distinctive struggles in and through education. The special issue also illustrates the diversity of Native peoples in dialogues surrounding sustainability and education in the Americas, Africa and the Pacific - a sharing of ideas, practices, initiatives and visions that foster international networks of learning.

To privilege local epistemologies, axiologies, ontologies and multiple systems of learning - including local worldviews, languages and cultural practices, as this special issue does - is to take a stand against coloniality and the death project. Indeed, the contributions that have been localised or erased in coloniality are globally relevant and pivotal to our common endeavour of thinking and working towards a world in which life is respected and cherished.

We begin with "Indigenous knowledge practices for sustainable lifelong education in pastoralist communities of Kenya", in which John Teria Ng'asike (Turkana) ${ }^{70}$ ethnographically explores early childhood education, literacy efforts and schooling among the Turkana. In postcolonial Kenya, where Kiswahili and English are dominant, he analyses how modern school curricula alienate local knowledge,

\footnotetext{
68 Takayama K., Sriprakash, A., \& Connel R. (2016). Toward a postcolonial comparative and international education. Comparative Education Review, 61(S1), S1-S24.

69 Wolfe, P. (2006). Settler colonialism and the elimination of the Native. Journal of Genocide Research, $8(4), 387-409$.

${ }^{70}$ It is thought that the Turkana people moved to their present area in the Northwest of Kenya from northeastern Uganda about two centuries ago. Their language is Turkana, an Eastern Nilotic language, and to this day, the Turkana continue to practise a nomadic pastoralist lifestyle. Their livestock include camels, zebu, donkeys and goats, which they move from one grazing area to the next.
} 
mother-tongue and Turkana knowledge resources. Because early childhood education departs from the contexts and realities of these pastoralist communities, students experience poor academic success rates. In presenting these data, $\mathrm{Ng}$ 'asike also challenges the notion that education is the "cure for poverty", showing how Indigenous knowledge in educational design is critical for ensuring access and sustainability of education in Turkana pastoralist communities. Moreover, he presents a family literacy project he was involved in which collected stories from elders and made them into storybooks, thereby creating tailor-made, meaningful instruction materials for early literacy practice.

Sharon Nelson-Barber (Rappahannock) $)^{71}$ and Zanette Johnson's article, "Raising the standard for testing research-based interventions in Indigenous learning communities", provides a comparative case to Ng'asike's, addressing how US educational institutions and governmental organisations that purport "best practices" are based on the values and norms of the dominant, middle-class American society. To illustrate this, the authors present three examples from Diné (Navajo) ${ }^{72}$ public schools that show how "best practices" have little bearing on local contexts of learning. To accurately assess learning outcomes, Nelson-Barber and Johnson argue that it is critical for educational institutions and governmental agencies to use multiple lenses and diverse assessment strategies; current "scientifically based" interventions may not only be ineffective, they may also actively inhibit learner achievement. Instead, standards are needed that hold education research and practice accountable to local contexts, adapting pedagogical strategies in response to uniquely situated communities.

Rosalva Mojica Lagunas (Nahua) ${ }^{73}$ takes up issues of Indigenous language loss and reclamation in Guerrero, Mexico. Her article, "Nahuatl in Coatepec: Ideologies, practices and management for linguistic and cultural continuance", addresses the rapid decline of Nahuatl-speaking ability among younger generations. Importantly, this article ethnographically explores the mechanisms through which language ideologies, family-community language management strategies and everyday inter-generational language practices operate inside and outside of school. We are invited to conceive of education more broadly as Lagunas illustrates how Indigenous systems of community-based learning operate within and across generations, and discusses the implications for language loss and reclamation.

\footnotetext{
71 The Rappahannock people are Indigenous to the state of present-day Virginia in the US. For more information on Rappahannock cultural revitalisation efforts, see: https://www.washingtonpost.com/ local/virginia-politics/the-indians-were-right-the-english-were-wrong-a-virginia-tribe-reclaims-itspast/2018/11/21/2380f92c-e8f4-11e8-bbdb-72fdbf9d4fed_story.html?utm_term=.38f57b77a89d [accessed 4 January 2019].

72 Navajo (Diné) homelands stretch across what is known today as the Four Corners region of the US Southwest, where the borders of four US states conjoin. The Navajo Nation encompasses parts of three of those states: Arizona, New Mexico and Utah. For more information on the Navajo Nation, see: http:// www.navajo-nsn.gov [accessed 7 January 2019].

73 The Nahua people are Indigenous to what is present-day Mexico and El Salvador.
} 
In "Educate to perpetuate: Land-based pedagogies and community resurgence", Tsalagi $^{74}$ scholars Jeff Corntassel and Tiffanie Hardbarger explore transformative and anti-colonial education through perpetuation, which is commonly associated with the transmission of Indigenous knowledge across generations. As the authors note, perpetuation occurs outside of school-based sites, which the authors describe as "state-centred, colonial manifestations of power". Drawing on a case study of community practices in the Cherokee Nation, these authors examine strategies for fostering land-centred literacies as pathways to community resurgence and sustainability - the perpetuation of Indigenous knowledges and nationhood that occurs every day. The focus on these acts of resurgence provides insight into re-thinking gendered relationships, community health and sustainable practices.

In "Cangleska Wakan: The ecology of the sacred circle and the role of tribal colleges and universities", Sicangu Lakota ${ }^{75}$ scholars Cheryl Crazy Bull and Emily White Hat provide a historical overview of the development and evolution of tribal colleges and universities in the United States from 1968 to 1993 and from 1994 to today. Tribal colleges and universities have served as place-based institutions that have preserved tribal identity as they have also evolved into land-grant institutions ${ }^{76}$ to preserve tribal environmental and ecological knowledge and resources. Drawing on the sacred circle, Cangleska [circle] Wakan [mystery] in Lakota, to describe the circular relationship among place, engagement and identity, the authors demonstrate how education, career development, community engagement and research contribute to land use and management, preservation and sustainability.

The final two articles address questions of research methodology among and by Indigenous communities, particularly in how these methodologies differ from historically oppressive approaches to knowledge acquisition. The authors take up research as inextricable from historically European domination of scientific approaches to acquiring and producing knowledge that have been problematic for Indigenous populations. In "Transforming Indigenous research: Collaborative responses to historical research tensions", Peter Mataira (Māori), ${ }^{77}$ tackles the dilatory effects of research among Indigenous communities that have led to a mistrust due to histories of Western exploitation and misrepresentation. Mataira examines a transformative means to disrupt the norms of social sciences research and to both mobilise and advance Indigenous communities through

\footnotetext{
74 The Tsalagi people are Indigenous to the southeastern regions of the US and are represented by different political bodies, including (but not limited to) the Eastern Band of Cherokee Indians, the United Keetoowah Band of Cherokee Indians, and the Cherokee Nation. For more information on the Cherokee Nation, see: https://webtest2.cherokee.org/Default.aspx [accessed 7 January 2019].

75 The author's affiliation is Sicangu Lakota, peoples residing in present-day South Dakota in the US and affiliated with the Rosebud Sioux Tribe: https://www.rosebudsiouxtribe-nsn.gov [accessed 7 January 2019].

76 A land-grant institution in this case refers to a higher education institution with a specific relationship to the US Congress or federal government. This status related to Tribal Colleges and Universities is referred to in the authors' article, and more information regarding land-grant institutions can be found at, http://www.aplu.org/about-us/history-of-aplu/what-is-a-land-grant-university/index.html [accessed 7 January 2019].

77 The Māori people reside in Aotearoa, known as New Zealand in the English language.
} 
"Strengths-enhancing Evaluation Research" (SEER). SEER is an approach based on diversity, autonomy, culturally based interventions and localised ways of knowing for long-term sustainable impacts based on community empowerment and well-being. As Mataira affirms, such alternative approaches restore "integrity and value to Indigenous knowledges, cultures, histories and interventions to counter the systematic fragmentation that has served to deny the rights of and disempower Indigenous peoples."

Wrapping up the special issue, Elizabeth Sumida Huaman's (Wanka/Quechua) article, "Comparative Indigenous education research (CIER): Indigenous epistemologies and comparative education methodologies", encourages a global dialogue on the contributions of Indigenous knowledge to research in comparative and international education, specifically research on Indigenous education. Her arguments respond directly to the lack of representation of Indigenous and other minoritised peoples in the field of comparative and international education. Sumida Huaman proposes comparative Indigenous education research (CIER) that supports Indigenous peoples and communities in identifying research priorities, locating sites of research that highlight issues of universal concern, and engaging community-based responses that are locally and globally relevant.

We hope this special issue is the first of many to come in which Indigenous voices not only reach but transform the field of Comparative and International Education as well as multiple fields concerned with the intersection of education, environment and sustainable futures. Such research and scholarship by Indigenous peoples are scarce, yet vitally needed. We thank our contributing authors for taking up this challenge, and we invite our readers into the dialogue the authors incite, regarding our collective responsibilities as educators, researchers, community members and allies.

Publisher's Note Springer Nature remains neutral with regard to jurisdictional claims in published maps and institutional affiliations.

Miye Nadya Tom is a scholar of Native American (Walker River Paiute/Pomo) and Russian descent. She received her PhD from the University of Coimbra, Portugal. Her work on post/colonialisms and ethnicity/ race examines, from a comparative and international perspective, transforming institutions of learning and knowledge production to meet the educational needs of youth from underrepresented communities, including: Native Americans (USA), communities of African origin (Portugal), and Roma (Spain). Her scholarly work has been featured in the Comparative Education Review, the International Review of Education, and in Postcolonial Europe: Comparative Reflections after the Empire (edited by Lars Jensen et al., Rowman and Littlefield 2017). She has been updating her research on urban Native American education in the San Francisco Bay Area, California, where she has also been working in inclusive education, early child development and Applied Behaviour Analysis. She also writes poetry, which has been featured in News from Native California.

Elizabeth Sumida Huaman is associate professor of Comparative International and Development Education at the University of Minnesota, Twin Cities. An Indigenous comparative and international education researcher, her work focuses on the link between Indigenous environments, languages, and cultural and educational practices in the United States, Canada and Peru. Her research projects include collaborative studies with Indigenous communities and institutions regarding Indigenous knowledge systems and education; community-based education and environmental and sustainability studies; and Indigenous 
women's narratives in formal and non-formal education. Her most recent publications include works in Curriculum Inquiry, Anthropology and Education Quarterly, and the International Journal of Human Rights Education, and the book Indigenous innovations in higher education: Local knowledge and critical research (with Bryan McKJ Brayboy, Brill 2017).

Teresa L. McCarty is the GF Kneller Chair in Education and Anthropology and Faculty in American Indian Studies at the University of California, Los Angeles. A member of the National Academy of Education, her books include A World of Indigenous Languages: Politics, Pedagogies and Possibilities in Language Reclamation (2019, with S.E. Nicholas and G. Wigglesworth), Language Planning and Policy in Native America (2013), Indigenous Language Revitalization in the Americas (2016, with S.M. Coronel-Molina), and "To Remain an Indian" - Lessons in Democracy from a Century of Native American Education (2006, with K.T. Lomawaima). She is Principal Investigator on a US-wide study of Indigenous-language immersion schooling, funded by the Spencer Foundation of Chicago, IL. 